\title{
Infuse Concept Of Peace In Curriculum Development
}

\author{
Muhammad Naeem Butt, IER, KUST, Pakistan \\ Muhammad Iqbal, SUIT, Pakistan \\ Muhammad Naseer-Ud-Din, IER, KUST, Pakistan \\ Ishtiaq Hussain, IER, KUST, Pakistan \\ Niaz Muhammad, CRS, KUST, Pakistan
}

\begin{abstract}
The major objectives of the study were to find out what the curricula, prescribed in the subjects of English and Pakistan Studies of the secondary classes, contained to promote awareness among the students about their responsibilities to the concerned society, and whether or not the curricula promoted reflective or critical thinking skill amongst the students. To attain the said objectives questionnaires were floated to school teachers; while four curriculum planners were interviewed. It was concluded that Peace, Love, and Harmony was essential for developing reflective or critical thinking skill of the learners but the curricula neither promoted reflective or critical thinking skill amongst the students nor it cultivated a sense of civic responsibilities amongst the students in letter and spirit.
\end{abstract}

Keywords: Peace; Curricula; Reflective Thinking; Critical Thinking; Harmony; Civic Responsibility

\section{INTRODUCTION}

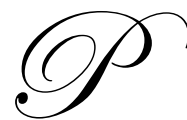

eace education is a terminology about which there seems to be not much awareness among the teachers and the taught. Peace education has not received the needed attention of curriculum planners and research in this area is scarce. Despite limited research, educational theorists and scholars like Peader Cremin, Mehmooda Rehman, and Susan Fountain have definitely clarified the concept of peace education and provided a platform to the government and educational authorities to infuse the concept of peace education in the curricula for the development of society.

Yousaf et al., (2010), described Peace education is educating all people for peace to satisfy their physical and social needs through individual and group action at the micro (interpersonal) and macro (local, national, and global inter group) levels. Educating all people for peace is only possible by developing altruism, friendship, beneficial relationships and by working cooperatively with others. Peace cannot be secured entirely by commercial interests, military alliances, general disarmament or mutual treaties, rather the spirit for peace needs to exist in the minds and will of the people and so it is necessarily a matter of Education

The growing violence and extremism have generated new interest in educationists to see what the curriculum contains and what has to be added to cultivate reflective thinking in students. There is a dire need to promote universal peace, love, and harmony in the schools through curriculum under the umbrella of "Love for All and Hatred for None" The present study is an analysis of the different aspects of Peace in the curricula of English and Pakistan Studies taught in secondary schools of North-West Frontier Province (N-W.F.P), Pakistan.

Rehman, Mehmooda (2006) stated that Peace is a vague word. For some it means silence, calm and quiet, while other perceive it is an "end to quarrel", no conflict, no war, no violence, or no dispute. Peace is the result of human efforts and has many components like satisfaction of the basic human needs; understanding, tolerance, respect, having harmony in society; order, justice and security in the society; non-violence and co-operation; absence of conflict and war; and love for all and hatred for none. 
Bretherton, et al (2002) stated "The aim of peace education is to draw out, enrich, deepen and place in context students' thinking about the concept of peace. The lesson to be learnt is not only the content of the concept but also its enactment and doing that is the methodology of peace. Given that peace is active and participatory, the pedagogy of peace education is crucially important. Peace is not only what is done but also a quality of the way in which it is done. While texts are important, the peace education curriculum will also use role -plays, games and collaborative learning projects. Group activities provide opportunities to learn about negotiation, cooperation and working together".

Peace education is most effective when the skills of peace and conflict resolution are learned actively and are modeled by the school environment in which pupils are taught (Baldo and Furniss, 1998). Educational programs have the potential to make strides at achieving peace through various educational efforts and processes in formal, non-formal, and informal education.

Cremin, Peader (1993) stated "It was understandable that in Hiroshima and Nagasaki peace education was almost exclusively equated with anti-nuclear bomb education. For many teachers, who were victims and survivors of the Atomic bomb attack, the core of peace education was nothing more than telling others about their own personal experience in August 1945".

Haris \& Morrison (1988) stated "Peace Education is currently considered to be both a philosophy and a process involving skill, including listening, reflection, problem solving, co-operation and conflict resolution. The process involves empowering people with the skills, attitude and knowledge to create a safe world and build a sustainable environment. The philosophy teaches nonviolence, love, compassion, and reverence for all life".

Fountain, Susan (1999) stated that internet, cd-rom, children's books, traditional folk stories, proverbs, art work and artifacts, and language teaching can be used as creative avenues to introduce peace education concepts, skills and attitudes, whether in or out of the school context.

\section{PROCEDURE OF THE STUDY}

The study attempted to explore the present status of peace in the curricula of English and Pakistan Studies taught in schools of North-West Frontier Province. Qualitative approach was used for data collection. The process involved interpretation of data and its conversion into percentages from which inferences were drawn.

\section{POPULATION OF THE STUDY}

All the secondary schools (both genders) in public and private sectors of rural and urban areas of Peshawar District constituted the population of this study.

\section{DELIMITATION OF THE STUDY} $10^{\text {th }}$.

The scope of the study was narrowed down to the subjects of English and Pakistan Studies of classes $9^{\text {th }} \&$

\section{SAMPLE}

The sample of the study included the curriculum in the subjects of English and Pakistan Studies prescribed for $9^{\text {th }}$ and $10^{\text {th }}$ classes. Twenty schools and 80 subject teachers were selected from Peshawar District. From those schools ten were selected each from private and government sectors of rural and urban areas. Four curriculum planners in all were interviewed. The simple random technique was used for the collection of data.

\section{RESEARCH INSTRUMENTS}

The research instruments included questionnaires and interviews. The instrument of the study included an open ended questionnaire for teachers, which contained 10 questions mainly asked them to respond on the items contained the objectives of the study. Questionnaires were floated to the subject teachers in the selected schools and 
data were collected personally from the respondents. Two types of interviews were held: face to face and telephonic from the curriculum planners. These interviews also elicited responses to the questions mainly based on the objectives of the study.

\section{DATA COLLECTION}

The primary data were collected from the questionnaires administered to the respondents, who were given reasonable time of one week. The interviews were held with the key informants, such as curriculum planners and teachers, on the basis of pre scheduled interviews.

\section{ANALYSIS OF THE DATA}

The data collected from teachers and curriculum planners, through questionnaires and interviews respectively, were analyzed and the variation in the opinion of the respondents was elicited with the help of percentage method.

\section{RESULT AND DISCUSSION}

This section is confined to the analysis and interpretation of the data obtained from questionnaires and interviews. The views of the respondents were made meaningful with the help of percentages. The results revealed that $55 \%$ of the respondents answered that the curricula did not promote the civic responsibilities amongst the students. $94 \%$ of the respondents were of the view that peace, love, and harmony is very essential for the development of reflective thinking skill amongst the learners, while $100 \%$ respondents were of the opinion that the curricula did not promote the reflective thinking skill amongst the learners.

Table 1: Importance of Peace, Love, and Harmony in Curriculum

\begin{tabular}{|c|c|c|c|}
\hline & A & B & Total \\
\hline Frequency & 75 & 5 & $\mathbf{8 0}$ \\
\hline Percent & $93.8 \%$ & $6.3 \%$ & $\mathbf{1 0 0}$ \\
\hline
\end{tabular}

The results of the data analyzed in Table-1 were mentioned under two categories of responses (A and B) and further illustrated through Graph (Figure-1).

1. Out of 80 respondents, 75 were of the view that peace, love, and harmony were very significant in both the subjects in order to develop reflective or rational thinking skill. The language of English could easily develop reflective or rational thinking and Pakistan studies, with the help of peace, love, and harmony could also change the ideology of the students.

2. The remaining 05 respondents believed that the subjects of English and Pakistan Studies did not have peace, love, and harmony in the content and, therefore, did not develop reflective or rational thinking.

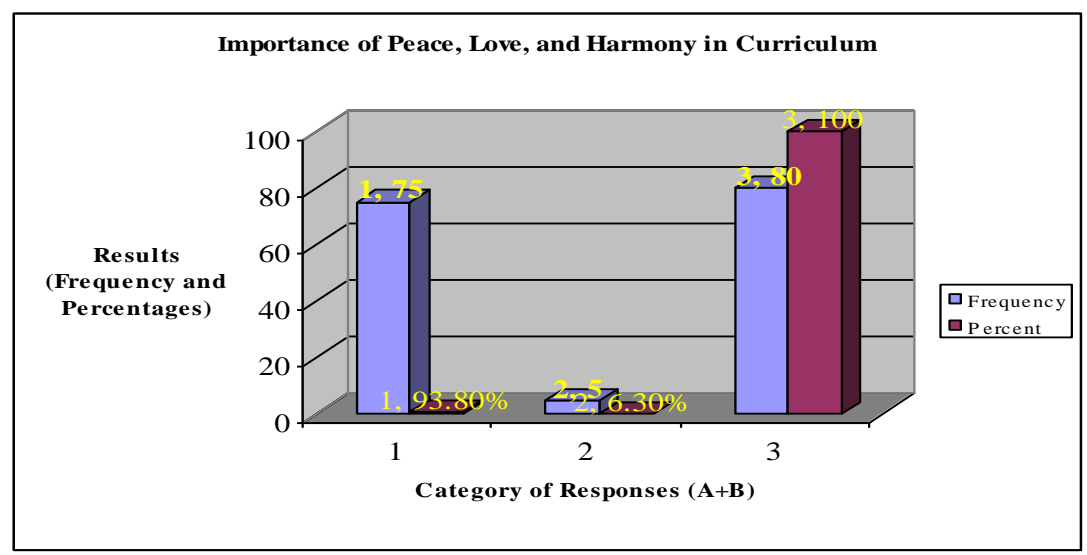

Figure-1: Importance of Peace, Love, and Harmony in Curriculum 


\section{CONCLUSIONS}

In the light of analysis and findings of this study, the following conclusions were drawn:

1. On the whole the curriculum did not promote the civic responsibility amongst the students at secondary level.

2. Peace, Love, and Harmony are very essential for the development of reflective thinking skill amongst the learners at secondary level.

3. The curricula of English and Pakistan Studies did not promote reflective thinking skill amongst the students.

4. Development of reflective or critical thinking skill in the students was considered essential and it could only be cultivated if the elements of Peace, Love, and harmony would be incorporated in the curricula of English and Pakistan studies through the exercises at the end of the lessons, which would contain the elements of Peace, Love, and harmony.

5. Inappropriate polices of Textbook Board and Federal Curriculum Wing, lack of awareness and professionalism of the teachers, neutrality of schools, social and financial issues are the obstacles, which hampered the achievement of the goal of Peace education.

\section{AUTHOR INFORMATION}

Mr.Muhammad Naeem Butt is working as Lecturer in Institute of Education and Research, Kohat University of Science and Technology, Kohat, Pakistan.. He did his M.Phil in Education from Sarhad University of Science and Technology, Peshawar - Pakistan nb840@yahoo.com

Dr. Muhammad Iqbal is presently working as Professor of Education in Department of Education, Sarhad University of Science and Technology, Peshawar - Pakistan

Dr. Muhammad Naseer-Ud-Din is working as an Assistant Professor in Institute of Education and Research, Kohat University of Science and Technology, Kohat, Pakistan. He did his Ph.D. in Education from University Institute of Education and Research, UAAR, Pakistan. E-mail: naseer_khanpk2000@ yahoo.com

Dr. Ishtiaq Hussain is working as an Assistant Professor in Institute of Education and Research, Kohat University of Science and Technology, Kohat, Pakistan.

Dr. Niaz Muhammad is working as an Assistant Professor in Central Religious Studies, Kohat University of Science and Technology, Kohat, Pakistan.

\section{REFERENCES}

1. Baldo, M., and Furniss, E., (1998). 'Integrating life skills into the primary curriculum'. New York, UNICEF.

2. Bretherton, D., Weston, J., \& Zbar, V. (2002). Peace Education Curriculum Development in Post-conflict Contexts: International Conflict Resolution Centre, the University of Melbourne, Parkville, VIC, Australia. (p. 3)

3. Cremin, P. (1993). Ed., Education for Peace, Educational Studies Association of Ireland and the Irish Peace Institute. (p. 15)

4. Fountain, S. (1999). Peace Education in UNICEF. New York: United Nations Children's Fund Programme Publications 3 UN Plaza New York. USA. (p.27)

5. Harris, I. M., \& Morrison, M. L. (2003). Peace Education. $2^{\text {nd }}$ edition, McFarland \& Co. New York, USA. (p. 9)

6. Rehman, M. (2006). Training Manual on Gender Equality and Peace Education, Basic Education for Afghan Refugee (BFARe), Peshawar, Pakistan. (p. 1)

7. Yousuf, M.I., Sarwar, M, Darth, G Naseer-ud-Din,. (2009). Peace Perceptions of Prospective Teachers for Promoting Peace Activities for School Settings in Pakistan. Journal of Diversity Management. 1(5), 1-5 